\title{
Effect of different levels of sewage sludge (city- waste) and inorganic fertilizers on the yield attribute and quality of mustard (Brassica juncea
}

\author{
L.)
}

H.K. YADAV, ARUN A. DAVID, T. THOMAS AND SUSHIL KUMAR

\section{MEMBERS OF RESEARCH FORUM: \\ Corresponding author : \\ H.K. YADAV, Department of Soil \\ Science, Allahabad School of Agriculture, Sam Higginbottom Institute of Agricultural Technology and Sciences, ALLAHABAD (U.P.) \\ INDIA \\ Email: harendray3@gmail.com}

Co-authors :

ARUN A. DAVID AND T. THOMAS,

Department of Soil Science, Allahabad

School of Agriculture, Sam

Higginbottom Institute of Agricultural

Technology and Sciences, ALLAHABAD

(U.P.) INDIA

SUSHIL KUMAR, Department of Agriculture Chemistry and Soil

Science, Ch. Chhotu Ram Degree

College, MUZAFFARNAGAR

(U.P.) INDIA

Received : 01.10.2014; Revised : 22.10.2014; Accepted : 09.11.2014

\section{Summary}

The influence of sewage-sludge and inorganic fertilizers (NPK) on growth, yield and quality of mustard was assessed from a field experiment on loamy soil in Rabi season of 2010-11. The levels of sewage sludge and inorganic fertilizers (NPK). The plant height $(\mathrm{cm})$, seed yield $\left(\mathrm{q}\right.$ ha $\left.{ }^{-1}\right)$ and content of oil and protein were significantly increased by the application of both sewage-sludge and inorganic fertilizer. The maximum growth and yield was obtained by the sewage-sludge application @ $12 \mathrm{t} \mathrm{ha}^{-1}$ and by the 75 per cent inorganic fertilizer. The interaction between sewage-sludge and inorganic fertilizer was found significant and the maximum increase in the growth, yield, oil (\%) and protein (\%) was obtained by applied sewage-sludge @ $12 \mathrm{t} \mathrm{ha}^{-1}$ and 75 per cent NPK. Four level of sewage-sludge (@ 0, 4, 8 and $12 \mathrm{t} \mathrm{ha}^{-1}$ ) through city waste and four level of inorganic fertilizers (@0,50,75 and 100 per cent of recommended dose were evaluated.

Key words : Sewage-sludge, Inorganic fertilizers, Yield, Quality and mustard

How to cite this article : Yadav, H.K., David, Arun A., Thomas, T. and Kumar, Sushil (2014). Effect of different levels of sewage sludge (city-waste) and inorganic fertilizers on the yield attribute and quality of mustard (Brassica juncea L.). Asian J. Soil Sci., 9(2): 256-260. 